\title{
PENERAPAN METODE EXPONENTIALLY WEIGHTED MOVING AVERAGE (EWMA) DALAM PENGUKURAN RISIKO INEVSTASI SAHAM PORTOFOLIO UNTUK VOLATILITAS HETEROGEN
}

\author{
Heni Dwi Wulandari ${ }^{1}$, Mustafid ${ }^{2}$, Hasbi Yasin. ${ }^{3}$ \\ 1,2,3 Departemen Statistika, Fakultas Sains dan Matematika, Universitas Diponegoro \\ e-mail : mustafid55@gmail.com
}

\begin{abstract}
Risk measurement is important in making an investment. One tool used in the measurement of investment risk is Value at Risk (VaR). VaR represents the greatest possible loss of investment with a given period and level of confidence. In the calculation of Value at Risk requires the assumption of normality and homogeneity. However, financial data rarely satisfies that assumption. Exponentially Weighted Moving Average is one method that can be used to overcome the existence of a heterogeneous variant. Daily volatility is calculated using the EWMA method by taking a decay factor of 0.94. VaR portfolio of ASII, BBNI and PTBA stocks is calculated using historical simulation method from the revised portfolio return with Hull and White volatility updating procedure. VaR values obtained are valid at a $99 \%$ confidence level based on the validity test of Kupiec PF and Basel rules.
\end{abstract}

Keywords: Value at Risk (VaR), Portfolio, EWMA, Historical Simulation, Volatility Updating

\section{PENDAHULUAN}

Kegiatan yang dilakukan investor dalam pasar modal biasanya mempertimbangkan tingkat pengembalian (return) dan risiko (risk). Salah satu kegiatan yang dilakukan dalam pasar modal adalah jual beli saham. Investor perlu menetapkan strategi tertentu untuk meminimalisir risiko yang mungkin terjadi. Salah satu risiko tersebut bisa disebabkan karena pergerakan harga saham. Dalam penerapan teori finansial, risiko didefinisikan sebagai volatilitas dari harga saham. Volatilitas merupakan ukuran ketidakpastian dari pergerakan suatu asset finansial pada waktu yang akan datang. Semakin besar tingkat volatilitas return saham, maka semakin besar pula kecenderungan harga saham tersebut naik atau turun. Dengan kata lain harga saham tersebut cenderung sangat mudah berubah, sehingga dapat disimpulkan bahwa tingkat risiko saham tersebut semakin besar.

Volatilitas dapat diukur dari simpangan baku (standar deviasi) rata-rata return saham per satuan waktu. Salah satu alat yang cukup baik untuk mengukur risiko investasi yaitu Value at Risk (VaR). VaR merupakan estimasi kerugian maksimum yang mungkin dialami dalam rentang waktu tententu dengan tingkat kepercayaan tertentu. Dalam perhitungan VaR, indikator yang digunakan adalah volatilitas $(\sigma)$. Variabel standar deviasi dalam perhitungan VaR diasumsikan berdistribusi normal. Namun pada kenyataannya, asumsi distribusi normal sulit dipenuhi untuk data keuangan. Maka digunakan metode historical simulation (HS) sebagai salah satu metode perhitungan VaR yg tidak mengharuskan asumsi normalitas. Selain itu, kebanyakan data finansial yang cenderung mempunyai volatilitas yang tidak konstan atau bersifat heteroskedastik. Salah satu pendekatan yang digunakan untuk mengatasi volatilitas yang tidak konstan adalah metode Exponentially Weighted Moving Average (EWMA) (Hull dan White, 1998). Penelitian ini akan menghitung VaR dengan menggunakan metode EWMA yang akan digunakan sebagai gambaran umum risiko pasar mengenai portofolio di Indonesia dan penerapannya menggunakan GUI Matlab. Software yang digunakan dalam penelitian ini adalah Matlab 9. 


\section{TINJAUAN PUSTAKA}

\subsection{Pasar Modal}

Pasar modal adalah tempat pasar terorganisasi yang memperdagangkan sahamsaham dan obligasi-obligasi dengan memakai jasa dari makelar, komisioner dan para underwriter (Ahmad, 2004). Pasar modal adalah tempat atau sarana bertemunya antara permintaan dan penawaran atau instrumen keuangan jangka panjang, umumnya lebih dari satu tahun (Samsul, 2006).

\subsection{Return}

Return adalah pendapatan yang akan diterima jika investor menginvestasikan uang pada suatu aktiva finansial (saham, obligasi) atau aktiva riil (Ghozali, 2006). Investasi merupakan penempatan sejumlah dana pada saat ini dengan harapan untuk memperoleh keuntungan di masa mendatang (Fahmi dan Hadi, 2011). Salah satu bentuk investasi di pasar modal adalah saham. Saham adalah salah satu komoditas keuangan yang diperdagangkan di pasar modal yang paling populer (Hadi, 2003). Saham merupakan salah satu efek atau sekuritas yang populer diperdagangkan di pasar modal. Saham adalah bukti kepemilikan terhadap suatu perusahaan (Sitompul, 1996).

Menurut Jorion (2002), return suatu asset dapat dihitung dengan rumus sebagai berikut:

dengan, $R_{t} \quad$ : return pada periode ke $\mathrm{t}$

$$
R_{t}=\ln \frac{P_{t}}{P_{t-1}}
$$

$P_{t} \quad$ : harga aset pada periode ke $\mathrm{t}$

$P_{t-1}$ : harga aset pada periode ke t-1

\subsection{Risiko}

Dalam setiap investasi untuk mendapatkan keuntungan selalu muncul potensi adanya risiko kerugian yang akan timbul apabila target keuntungan investasi tersebut tidak sesuai dengan yang direncanakan dan yang diinginkan. Setiap tindakan investasi mempunyai tingkat risiko dan keuntungan yang berbeda-beda. Risiko investasi yang timbul dari setiap investasi kadang bisa diprediksikan sebelumnya, kadang tidak bisa diprediksikan.

Alat ukur risiko yaitu volatilitas yang merupakan ukuran dispersi dari suatu aset, serta Value at Risk (VaR) yaitu besarnya risiko yang mungkin dialami dalam tingkat kepercayaan tertentu (Ghozali, 2007). Menurut Jorion (2002), jika terdapat n (jumlah observasi) return maka nilai expected return dapat diperoleh dengan rumus:

$$
E\left(R_{i}\right)=\mu_{i}=\frac{1}{n} \sum_{t=1}^{n} R_{i t}
$$

Sedangkan varian tiap periode diukur dengan:

$$
\operatorname{Var}\left(R_{i}\right)=s_{i}^{2}=\frac{1}{n-1} \sum_{t=1}^{n}\left(R_{i t}-\mu_{i}\right)^{2}
$$

dengan, $R_{i t} \quad:$ Return aset ke-i pada waktu ke-t

$\mu_{i} \quad$ : Rata-rata return aset ke-i

n : Jumlah observasi

$\mathrm{s}_{\mathrm{i}}{ }^{2}$ : Varian aset ke-i

Akar dari $s_{i}{ }^{2}$ disebut sebagai standar deviasi adalah volatilitas atau estimasi risiko dari suatu aset. 


\subsection{Portofolio}

Portofolio merupakan salah satu langkah investasi yang melibatkan beberapa aset, yaitu ketika investor berinvestasi pada lebih dari satu aset.Teori ini mengajarkan bagaimana mengkombinasikan saham-saham ke dalam suatu portofolio untuk memperoleh keuntungan maksimal dengan risiko tertentu, atau memperoleh keuntungan dengan risiko minimal.

Menurut Jorion (2002), return portofolio dihitung dengan persamaan berikut:

$$
R_{p, t}=\sum_{i=1}^{N} w_{i} R_{t, i}
$$

dengan, $R_{p, t}$ : return portofolio pada waktu ke- $t$

$R_{t, i} \quad$ : return pada waktu ke- $t$ untuk aset ke- $i$

$w_{i} \quad$ : bobot untuk aset ke- $i$

$N \quad$ : jumlah aset

Return portofolio ditulis menggunakan notasi matriks sebagai berikut:

$$
R_{p}=w_{1} R_{1}+w_{2} R_{2}+\cdots+w_{N} R_{N}=\left[\begin{array}{llll}
w_{1} & w_{2} & \cdots & w_{N}
\end{array}\right]\left[\begin{array}{c}
R_{1} \\
R_{2} \\
\vdots \\
R_{N}
\end{array}\right]=\boldsymbol{w}^{T} \boldsymbol{R}
$$

dengan, $\boldsymbol{w}^{T}$ : transpose vektor bobot

$\boldsymbol{R}$ : vektor return aset tunggal

Menurut Ghozali (2007), dalam pembentukan portofolio diperlukan perhitungan kovarian. Secara matematis kovarian return saham A dan B dirumuskan sebagai berikut:

$$
s_{A, B}=\frac{\sum_{t=1}^{T}\left[\left(R_{t, A}-E\left(R_{A}\right)\right)\left(R_{t, B}-E\left(R_{B}\right)\right)\right]}{T-1}
$$

Matriks varian kovarian juga diperlukan dalam pembentukan portofolio. Matriks varian kovarian $(\boldsymbol{S})$ untuk dua saham adalah:

$$
\boldsymbol{S}=\left[\begin{array}{cc}
s_{A}^{2} & s_{B, A} \\
s_{A, B} & s_{B}^{2}
\end{array}\right]
$$

Risiko portofolio merupakan risiko investasi dari sekelompok aset dalam portofolio. Menurut Jorion (2002), varian portofolio dengan $N$ aset saham dihitung dengan persamaan berikut:

$$
s_{p}^{2}=\sum_{i=1}^{N} w_{i}^{2} s_{i}^{2}+2 \sum_{i=1}^{N} \sum_{j<i}^{N} w_{i} w_{j} s_{i j}
$$

\subsection{Mean Variance Efficient Portfolio (MVEP)}

Menurut Maruddani dan Purbowati (2009), Mean Variance Efficient Portofolio (MVEP) merupakan salah satu metode dalam pembentukan portofolio optimal. Menurut Fauziah dkk (2012), MVEP didefinisikan sebagai portofolio yang memiliki varian minimum diantara keseluruhan kemungkinan portofolio yang dapat dibentuk. Hal tersebut sama dengan mengoptimalisasi bobot $\boldsymbol{w}=\left[w_{1} \ldots w_{N}\right]^{T}$ berdasarkan maksimum mean risiko dari varian yang diberikan. Secara lebih formal, dicari vektor pembobotan $\boldsymbol{w}$ agar portofolio yang dibentuk mempunyai varian yang minimum berdasarkan dua batasan yaitu:

1. Spesifikasi awal dari mean risiko $\mu_{p}$ harus tercapai yaitu $\boldsymbol{w}^{T} \boldsymbol{\mu}$.

2. Jumlah proporsi dari portofolio yang terbentuk sama dengan 1 yaitu $\boldsymbol{w}^{T} \mathbf{1}_{N}=1$, dimana $\mathbf{1}_{N}$ adalah vektor satuan dengan dimensi $\mathrm{N}$ x 1 . 
Permasalahan optimalisasi dapat diselesaikan dengan fungsi Lagrange yaitu:

$$
L=\boldsymbol{w}^{T} \boldsymbol{S} \boldsymbol{w}+\lambda_{1}\left(\mu_{p}-\boldsymbol{w}^{T} \boldsymbol{\mu}\right)+\lambda_{2}\left(1-\boldsymbol{w}^{T} \mathbf{1}_{N}\right)
$$

dengan, $L$ : fungsi Lagrange

$\lambda$ : faktor pengali Lagrange yaitu:

Untuk mendapatkan nilai optimal $\boldsymbol{w}$, persamaan diatas diturunkan parsial terhadap $\boldsymbol{w}$

$$
\begin{gathered}
\frac{\partial L}{\partial \boldsymbol{w}}=0 \\
\frac{\partial}{\partial \boldsymbol{w}}\left[\boldsymbol{w}^{T} \boldsymbol{S} \boldsymbol{w}+\lambda_{1}\left(\mu_{p}-\boldsymbol{w}^{T} \boldsymbol{\mu}\right)+\lambda_{2}\left(1-\boldsymbol{w}^{T} \mathbf{1}_{N}\right)\right]=0
\end{gathered}
$$

Maka diperoleh persamaan pembobotan pada MVEP adalah:

dimana $\boldsymbol{S}^{-1}$ : invers matriks varian-kovarian.

$$
\boldsymbol{w}=\frac{\boldsymbol{S}^{-1} \mathbf{1}_{N}}{\mathbf{1}_{N}{ }^{T} \boldsymbol{S}^{-1} \mathbf{1}_{N}}
$$

Turunan kedua fungsi Lagrange terhadap bobot merupakan syarat mencapai minimum:

$$
\frac{\partial^{2} L}{\partial w^{2}}=2 S
$$

dimana elemen-elemen dalam matriks $2 \boldsymbol{S}>0$.

\subsection{Exponentially Weighted Moving Average (EWMA)}

EWMA merupakan salah satu pendekatan untuk menghadapi volatilitas data yang tidak konstan (Morgan, 1996). Metode ini memberikan bobot terhadap perubahan harga setiap periode dengan menggunakan decay factor $(\lambda)$. Parameter $\lambda$ menunjukkan skala bobot atas pengamatan data terbaru dengan data sebelumnya dengan nilai $0<\lambda<1$. Semakin tinggi nilai $\lambda$ maka akan semakin besar pula bobot yang akan dikenakan pada data masa lampau sehingga data runtun waktu semakin smooth. Persamaan EWMA yang digunakan adalah sebagai berikut :

dengan, $s_{t}^{2} \quad$ : varian data return pada periode $\mathrm{t}$

$$
s_{t}^{2}=\lambda s_{t-1}^{2}+(1-\lambda) R_{t-1}^{2}
$$

$s_{t-1}^{2} \quad$ : varian data return pada periode t-1

$R_{t-1}$ : return pada periode $\mathrm{t}-1$

$\lambda \quad$ : parameter (decay factor)

Nilai $\lambda$ menunjukkan skala bobot 0-1 dari pengamatan data terbaru dengan data sebelumnya. Semakin tinggi nilai $\lambda$ pada sebuah data return berarti semakin besar pengaruh volatilitas sebelumnya, namun semakin tidak reaktif terhadap informasi pasar terakhir. Sebaliknya semakin kecil nilai $\lambda$ maka semakin reaktif volatilitas tersebut terhadap informasi pasar sebelumnya. Menurut Jorion (2002), Risk Metrics menggunakan nilai $\lambda$ sebesar 0,94 untuk data harian, sedangkan nilai $\lambda$ sebesar 0,97 digunakan untuk observasi data bulanan.

\subsection{Volatility Updating Hull ang White}

Menurut Hull dan White (1997), jika volatilitas dari variabel pasar stasioner maka diperlukan pembaharuan volatilitas yang dilakukan dengan metode historical simulation. Updating volatility dilakukan berdasarkan rumus:

$$
R_{j, t}^{*}=s_{j, T} \frac{R_{j, t}}{s_{j, t}}
$$

dengan, $R_{j, t}^{*}$ : return asset $\mathrm{j}$ yang diperbaharui pada hari ke $\mathrm{t}$

$R_{j, t}$ : return asset $\mathrm{j}$ pada hari ke $\mathrm{t}$

$s_{j, T}$ : hasil estimasi volatilitas harian EWMA yang terbaru 
$s_{j, t}$ : volatilitas return harian diestimasi dengan EWMA untuk asset $\mathrm{j}$ pada hari $\mathrm{t}$ Diasumsikan distribusi probabilitas $\left(R_{j, t} / s_{j, t}\right)$ bersifat stasioner (Hull dan White, 1998).

\subsection{Value at Risk (VAR)}

VaR merupakan pengukuran kemungkinan kerugian terburuk dalam kondisi pasar yang normal pada kurun waktu T dengan tingkat kepercayaan $\alpha$ tertentu (Moorgan, 1996). Value at Risk adalah ukuran perubahan potensial maksimum dalam nilai portofolio instrumen keuangan dengan probabilitas tertentu di atas cakrawala yang telah ditentukan sebelumnya. Menurut Jorion (2002), secara sederhana Value at Risk (VaR) menjawab pertanyaan seberapa besar (dalam persen atau sejumlah uang tertentu) investor dapat merugi selama waktu investasi $t$ dengan tingkat kepercayaan (1- $\alpha)$.

\subsection{Metode Historical Simulation}

Menurut Jorion (2002), metode historical simulation merupakan metode yang paling mudah digunakan karena tidak ada asumsi return yang harus dipenuhi seperti return harus berdistribusi normal maupun sifat linier antara return portofolio dan return aset tunggalnya. Rumus yang digunakan untuk menghitung nilai VaR dengan menggunakan metode Historical Simulation adalah sebagai berikut :

dimana, VaR: Estimasi kerugian maksimal

$$
\text { VaR }=S_{0} \times \text { Percentile } \alpha \times \sqrt{h p}
$$

$S_{0} \quad$ : Dana awal

$h p$ : Holding period

Percentile $\alpha$ merupakan data ke $N \times \alpha$ dari return portofolio yang sudah diurutkan mulai nilai terkecil hingga terbesar.

\subsection{Pengujian Asumsi}

\subsubsection{Asumsi Normalitas}

Sebelum dilakukan perhitungan VaR, terlebih dahulu dilakukan uji asumsi kenormalan data. Pengujian ini berhubungan dengan ketepatan persebaran data dalam mengikuti distribusi normal, hal ini untuk menentukan apakah diperlukan penyesuaian terhadap tingkat keyakinan yang digunakan. Hipotesis yang digunakan adalah:

$\mathrm{H}_{0}$ : data return saham berdistribusi normal

$\mathrm{H}_{1}$ : data return saham tidak berdistribusi normal

Menurut Mutaqin dan Hakim (2006), statistik uji yang digunakan untuk pengujian asumsi normalitas adalah nilai Jarque-Bera. Mencari nilai Jarque-Bera menggunakan persamaan sebagai berikut:

dengan, $J B \quad$ : nilai Jarque-Berra

$$
J B=n\left(\left(\frac{S^{2}}{6}\right)+\left(\frac{(K-3)^{2}}{24}\right)\right)
$$

$$
\begin{array}{ll}
\mathrm{n} & \text { : jumlah Data } \\
S & \text { : nilai skewness } \\
K & \text { : nilai kurtosis }
\end{array}
$$

Apabila nilai Jarque- Berra lebih kecil dari nilai Chi-Square $\left(X^{2}\right)$ dengan derajat bebas 2 atau nilai $p$-value $>$ taraf signifikansi, maka $\mathrm{H}_{0}$ diterima artinya data berdistribusi normal.

\subsubsection{Asumsi Stasioneritas}

Uji asumsi stasioneritas dilakukan untuk mengetahui apakah data sudah terbebas dari autokorelasi dan data sudah bersifat acak. Data yang dikatakan stasioner adalah data yang 
tidak mengandung trend, bersifat setara serta tidak terdapat fluktuasi periodik atau musiman. Menurut Tsay (2005), uji stasioneritas menggunakan Augmented Dickey-Fuller Test (Uji ADF) dilakukan dengan menguji hipotesis berikut:

$\mathrm{H}_{0}: \beta=1$ (terdapat akar unit atau data tidak stasioner)

$\mathrm{H}_{1}: \beta<1$ (tidak terdapat akar unit atau data stasioner)

Untuk menguji stasioneritas data digunakan persamaan regresi:

$$
x_{t}=c_{t}+\beta x_{t-1}+\sum_{i=1}^{p-1} \emptyset_{i} \Delta x_{t-i}+e_{t}
$$

Dengan $c_{t}$ adalah fungsi deterministik dari indeks waktu t dan $\Delta x_{j}=x_{j}-x_{j-1}$ dari series yang didiferensi dari $x_{t}$. Dalam praktiknya $c_{t}$ dapat bernilai 0 atau konstan. Statistik uji yang digunakan adalah statistik t-rasio dari $\hat{\beta}-1$ yaitu:

$$
A D F=\frac{\hat{\beta}-1}{\operatorname{std}(\hat{\beta})}
$$

Jika nilai $\mathrm{ADF} \leq$ nilai pada tabel $\mathrm{ADF}$ atau probablility $\leq$ taraf signifikansi, maka $\mathrm{H}_{0}$ ditolak.

\subsubsection{Asumsi Heteroskedastisitas}

Uji asumsi heteroskedastisitas berhubungan dengan error variance dari data yang bersifat konstan atau tidak, hal ini akan digunakan dalam perhitungan VaR. Menurut Gujarati (2006), jika varian residual bervariasi dari observasi ke observasi, maka varian residual tersebut tidak sama atau bersifat heteroskedastik. Salah satu alat untuk pengujian heteroskedastisitas adalah uji Glejser. Misalkan uji ini diterapkan pada model berikut:

$$
Y_{i}=B_{0}+B_{1} X_{1}+B_{2} X_{2}+\varepsilon_{i}
$$

Langkah-langkah uji Glejser adalah sebagai berikut:

1. Estimasi model regresi dengan Ordinary Least Square (OLS) sehingga memperoleh residual $\varepsilon_{i}$.

2. Regresikan nilai absolut dari $\varepsilon_{i}$ terhadap variabel X. Dalam percobaannya Glejser menggunakan bentuk fungsional berikut:

$$
\begin{gathered}
\left|\varepsilon_{i}\right|=B_{1} X_{i}+v_{i} \\
\left|\varepsilon_{i}\right|=B_{1} \sqrt{X_{i}}+v_{i} \\
\left|\varepsilon_{i}\right|=B_{1} \frac{1}{X_{i}}+v_{i} \\
\left|\varepsilon_{i}\right|=B_{1} \frac{1}{\sqrt{X_{i}}}+v_{i} \\
\left|\varepsilon_{i}\right|=B_{0}+B_{1} X_{i}+v_{i} \\
\left|\varepsilon_{i}\right|=\sqrt{B_{0}+B_{1} X_{i}}+v_{i} \\
\left|\varepsilon_{i}\right|=\sqrt{B_{0}+B_{1} X_{i}^{2}}+v_{i}
\end{gathered}
$$

dimana $v_{i}$ adalah tingkat kesalahan.

3. Pengujian heteroskedastisitas dilakukan menggunakan hipotesis berikut:

$\mathrm{H}_{0}$ : data return saham bersifat tidak heteroskedastis (varian konstan)

$\mathrm{H}_{1}$ : data return saham bersifat heteroskedastis(varian tidak konstan)

4. Jika koefisien $B_{1}$ bersifat tidak signifikan atau jika nilai $p$-value < taraf signifikansi, maka $\mathrm{H}_{0}$ diterima artinya asumsi homoskedastisitas dapat diterima.

Apabila data diketahui bersifat homoskedastis, maka $\sigma$ dihitung dengan rumus berikut:

$$
\sigma=\sqrt{\frac{\sum_{i=1}^{n}(R-\bar{R})^{2}}{n-1}}
$$

Apabila data bersifat heteroskedastis, maka $\sigma$ dihitung dengan pendekatan EWMA. 


\subsection{Backtesting}

Menurut Jorion (2002), model VaR hanya bermanfaat bila dapat memprediksikan risiko dengan baik. Langkah yang dilakukan dalam backtesting adalah membandingkan kerugian sebenarnya dengan kerugian yang diprediksi oleh model VaR. Tabel berikut memberikan batasan untuk tidak menolak model setelah dilakukan backtesting.

Tabel 1. Besaran Kesalahan untuk tidak Menolak Model VaR

\begin{tabular}{cccc}
\hline Tingkat & \multicolumn{3}{c}{ Tidak Menolak Batasan untuk $\mathrm{m}$ Kesalahan } \\
\cline { 2 - 4 } Kepercayaan & $\mathrm{T}=255$ hari & $\mathrm{T}=510$ hari & $\mathrm{T}=1000$ hari \\
\hline $99 \%$ & $<7$ & $1<\mathrm{m}<11$ & $4<\mathrm{m}<17$ \\
$97,5 \%$ & $2<\mathrm{m}<12$ & $8<\mathrm{m}<21$ & $15<\mathrm{m}<36$ \\
$95 \%$ & $6<\mathrm{m}<21$ & $16<\mathrm{m}<36$ & $37<\mathrm{m}<65$ \\
$92,5 \%$ & $11<\mathrm{m}<28$ & $27<\mathrm{m}<51$ & $59<\mathrm{m}<92$ \\
$90 \%$ & $16<\mathrm{m}<36$ & $38<\mathrm{m}<65$ & $81<\mathrm{m}<120$ \\
\hline
\end{tabular}

Menurut Kupiec (1995), statistik uji terbaik berdasarkan tingkat kegagalan adalah dengan Likelihood ratio (LR). Hipotesis untuk pengujian backtesting adalah sebagai berikut: $\mathrm{H}_{0}$ : nilai VaR akurat $\mathrm{H}_{1}$ : nilai VaR tidak akurat

Statistik uji yang digunakan adalah LR dengan rumus berikut:

dengan, LR : Likelihood Ratio

$$
L R=-2 \ln \left[(1-p)^{T-m} p^{m}\right]+2 \ln \left[\left(1-\left[\frac{m}{T}\right]\right)^{T-m}\left(\frac{m}{T}\right)^{m}\right]
$$

$p$ : probabilitas kegagalan

$T$ : jumlah obervasi

$m$ : jumlah kegagalan

Jika nilai LR lebih besar daripada nilai kritis ditribusi Chi-Square dengan derajat bebas 1 , maka hipotesis nol ditolak.

\subsection{GUIDE}

Nama Matlab merupakan akronim dari kata Matrix Laboratory. Matlab merupakan sebuah program untuk menganalisis dan mengkomputasi data numerik. Matlab merupakan suatu bahasa pemrograman lanjutan yang dibentuk dengan dasar pemikiran yang menggunakan sifat dan bentuk matriks. GUI builder merupakan sebuah graphical user interface (GUI) yang dibangun dengan obyek grafik seperti tombol (button), kotak teks, slider, menu dan lain-lain. GUI pada Matlab dikenal dengan nama GUIDE. GUI pada Matlab merupakan sebuah aplikasi display dari Matlab yang mengandung komponen program yang mempermudah user atau pengguna dalam menjalankan sebuah program dalam Matlab.

\section{METODE PENELITIAN}

\subsection{Sumber Data dan Variabel Penelitian}

Data yang digunakan dalam penelitian ini adalah data sekunder, yaitu data penutupan harga saham (closing price) dengan periode waktu harian dari tiga perusahaan sejumlah 140 data yang dimulai tanggal 02 Januari 2017 sampai 25 Juli 2017. Data tersebut diperoleh dari situs http://finance.yahoo.com.

\subsection{Variabel Penelitian}

$\mathrm{P}_{1}$ : Data harga saham harian PT Astra Internasional Tbk. (ASII)

$\mathrm{P}_{2}$ : Data harga saham harian PT Bank Negara Indonesia Tbk (BBNI)

$\mathrm{P}_{3}$ : Data harga saham harian PT Tambang Batubara Bukit Asam Tbk. (PTBA) 


\subsection{Tahapan Analisis Data}

1. Menghitung nilai return dari masing-masing saham.

2. Menghitung nilai return portofolio berdasarkan MVEP.

3. Menguji stasioneritas data return masing-masing saham. Apabila tidak stasioner, maka dilakukan differencing.

4. Menguji normalitas data return masing-masing saham. Jika data berdistribusi normal maka dapat dilanjutkan untuk perhitungan return portofolio, sedangkan jika data tidak berdistribusi normal perhitungan nilai VaR dilakukan dengan metode historical simulation untuk masing-masing saham, kemudian dilanjutkan dengan pengujian heteroskedastisitas.

5. Menguji heteroskedastisitas data return masing-masing saham dengan. Apabila return bersifat homoskedastis, maka volatilitas dihitung dengan rumus $\sigma=\sqrt{\frac{\sum_{i=1}^{n}(R-\bar{R})^{2}}{n-1}}$. Apabila return bersifat heteroskedastis, maka perhitungan volatilitas menggunakan pendekatan EWMA.

6. Menghitung return baru dengan prosedur volatility updating Hull and White.

7. Menghitung portofolio dengan menggunakan data return baru.

8. Melakukan uji backtesting dari nilai VaR yang diperoleh dengan menggunakan aturan Basel dan Uji PF Kupiec.

\section{HASIL DAN PEMBAHASAN}

\subsection{Pengujian Asumsi}

\subsubsection{Asumsi Normalitas}

$\mathrm{H}_{0}$ : Data return berdistribusi normal

$\mathrm{H}_{1}$ : Data return tidak berdistribusi normal

Statistik uji yang digunakan adalah Jarque Bera: $J B=n\left(\left(\frac{S^{2}}{6}\right)+\left(\frac{(K-3)^{2}}{24}\right)\right)$

$\mathrm{H}_{0}$ ditolak apabila nilai $\mathrm{JB}>$ nilai $x_{\text {tabel }}^{2}$ dengan $\mathrm{db}=2$ atau nilai $p$-value $<\alpha$. Pada penelitian ini, nilai $\chi_{0,05 ; 2}^{2}=5,99148$. Hasil uji normalitas Jarque-Bera:

Tabel 2. Uji Normalitas Jarque-Bera

\begin{tabular}{cccc}
\hline Return & JB & P-value & Keputusan \\
\hline ASII & 0,710435 & 0,5 & $\mathrm{H}_{0}$ diterima \\
BBNI & 0,420055 & 0,5 & $\mathrm{H}_{0}$ diterima \\
PTBA & 0,552168 & 0,5 & $\mathrm{H}_{0}$ diterima \\
\hline
\end{tabular}

Berdasarkan Tabel 2, dengan mengambil taraf signifikansi $\alpha=5 \%$, dapat disimpulkan bahwa data return saham ASII, BBNI dan PTBA berdistribusi normal.

\subsubsection{Asumsi Stasioneritas}

$\mathrm{H}_{0}: \beta=1$ (terdapat akar unit atau data tidak stasioner)

$\mathrm{H}_{1}: \beta=0$ (tidak terdapat akar unit atau data stasioner)

Statistik uji dalam pengujian asumsi stasioneritas adalah: $A D F=\frac{\widehat{\beta}-1}{\operatorname{std}(\widehat{\beta})}$

$\mathrm{H}_{0}$ ditolak apabila nilai $p$-value $<\alpha$.

Tabel 3. Uji Stasioneritas Augmented Dickey-Fuller

\begin{tabular}{cccc}
\hline Return & P-Value & $\alpha$ & Keputusan \\
\hline ASII & 0,001 & 0,05 & $\mathrm{H}_{0}$ ditolak \\
BBNI & 0,001 & 0,05 & $\mathrm{H}_{0}$ ditolak \\
PTBA & 0,001 & 0,05 & $\mathrm{H}_{0}$ ditolak \\
\hline
\end{tabular}


Berdasarkan Tabel 3, dengan mengambil taraf signifikansi $\alpha=5 \%$, dapat disimpulkan bahwa data return saham ASII, BBNI dan PTBA bersifat stasioner.

\subsubsection{Asumsi Heteroskedastisitas}

$\mathrm{H}_{0}$ : data return saham bersifat tidak heteroskedastis (varian konstan)

$\mathrm{H}_{1}$ : data return saham bersifat heteroskedastis(varian tidak konstan)

Statistik uji dalam pengujian asumsi heteroskedastisitas adalah: $t$ hitung $=\frac{\widehat{\beta}}{\operatorname{std}(\widehat{\beta})}$

$\mathrm{H}_{0}$ ditolak apabila nilai $\mid \mathrm{t}$ hitung $\mid>\mathrm{t}_{\alpha, \mathrm{n}-1}$

Tabel 4. Uji Heteroskedastisitas Glejser

\begin{tabular}{cccc}
\hline Return & $\mathrm{t}$ hitung & $\mathrm{t}_{\alpha, \mathrm{n}-1}$ & Keputusan \\
\hline ASII & 24,9144 & 1,97730 & $\mathrm{H}_{0}$ ditolak \\
BBNI & 21,5487 & 1,97730 & $\mathrm{H}_{0}$ ditolak \\
PTBA & 18,0976 & 1,97730 & $\mathrm{H}_{0}$ ditolak
\end{tabular}

Berdasarkan Tabel 4, dengan mengambil taraf signifikansi $\alpha=5 \%$, dapat disimpulkan bahwa varian data return saham ASII, BBNI dan PTBA tidak konstan.

\subsection{Perhitungan VaR Historical Simulation}

\subsubsection{Pembentukan Portofolio Optimum}

1. Menghitung nilai rata-rata return saham ASII, BBNI dan PTBA

$$
\begin{gathered}
E(R)=\mu_{i}=\frac{1}{n} \sum_{i=1}^{n} R\left(P_{i t}\right) \\
\mu_{A S I I}=0,002302 \mu_{B B N I}=0,001235 \quad \mu_{P T B A}=-0,001069
\end{gathered}
$$

2. Menghitung varian return berdasarkan Persamaan:

$$
\begin{gathered}
\operatorname{Var}(R)=s_{i}{ }^{2}=\frac{1}{n-1} \sum_{i=1}^{n}\left(R\left(P_{i t}\right)-\mu_{i}\right)^{2} \\
s_{A S I I}^{2}=0,00004625 s_{B B N I}^{2}=0,0004247 \quad s_{P T B A}^{2}=0,0005394
\end{gathered}
$$

3. Menghitung kovarian berdasarkan persamaan:

$$
s_{A, B}=\frac{\sum_{t=1}^{T}\left[\left(R_{t, A}-E\left(R_{A}\right)\right)\left(R_{t, B}-E\left(R_{B}\right)\right)\right]}{T-1}
$$

$s_{A S I I, B B N I}=-0,0000349 s_{A S I I, P T B A}=0,0000009 s_{B B N I, P T B A}=-0,0000786$

4. Perhitungan bobot dilakukan dengan metode MVEP, dengan rumus:

$$
\begin{gathered}
\boldsymbol{w}=\left[\begin{array}{l}
w_{1} \\
w_{2} \\
w_{3}
\end{array}\right]=\frac{\sum^{-1} \mathbf{1}_{3}}{\mathbf{1}_{3}{ }^{T} \sum^{-1} \mathbf{1}_{3}} \\
\boldsymbol{w}=\left[\begin{array}{l}
w_{1} \\
w_{2} \\
w_{3}
\end{array}\right]=\frac{\left[\begin{array}{ccc}
2175,8 & 183 & 23,2 \\
183 & 2435,6 & 354,7 \\
23,2 & 354,7 & 1905,6
\end{array}\right]\left[\begin{array}{l}
1 \\
1 \\
1
\end{array}\right]}{\left[\begin{array}{lll}
1 & 1 & 1
\end{array}\right]\left[\begin{array}{ccc}
2175,8 & 183 & 23,2 \\
183 & 2435,6 & 354,7 \\
23,2 & 354,7 & 1905,6
\end{array}\right]\left[\begin{array}{l}
1 \\
1 \\
1
\end{array}\right]}=\left[\begin{array}{l}
0,311829 \\
0,389240 \\
0,298931
\end{array}\right]
\end{gathered}
$$

Dimana, $w_{1}$ merupakan bobot ASII sebesar 0,311829, $w_{2}$ merupakan bobot BBNI sebesar 0,389240 dan $w_{2}$ merupakan bobot PTBA sebesar 0,298931. Perhitungan return Portofolio: 


$$
\begin{gathered}
R_{p, t}=\boldsymbol{w}^{T} \boldsymbol{R} \\
R_{p, 1}=\boldsymbol{w}^{T} \boldsymbol{R}=\left[\begin{array}{c}
0,311829 \\
0,389240 \\
0,298931
\end{array}\right]^{T}\left[\begin{array}{c}
0,0000 \\
-0,0067 \\
0,0308
\end{array}\right]=0,00659
\end{gathered}
$$

Perhitungan return portofolio dilanjutkan hingga periode ke 139.

\subsubsection{Perhitungan Volatilitas dengan EWMA}

1. Varian harian pertama sama dengan varian return portofolio, nilai varian harian pertama, yaitu:

$$
\begin{aligned}
& \sigma_{1}^{2}=\operatorname{var}\left(R_{p, t}\right)=0,0001309 \\
& \sigma_{1}=\sqrt{\sigma_{1}^{2}}=\sqrt{0,0001309}=0,0114
\end{aligned}
$$

2. Varian harian kedua perhitungan dilakukan menggunakan rumus EWMA:

$\sigma_{t+1}^{2}=\lambda \sigma_{t}^{2}+(1-\lambda) R_{t}^{2}$

$\sigma_{2}^{2}=\sigma_{1+1}^{2}=\lambda \sigma_{1}{ }^{2}+(1-\lambda) R_{1}{ }^{2}$

$\sigma_{2}^{2}=(0,94 \times 0,0001309)+(1-0,94)(0,00659)^{2}=0,0001257$

$\sigma_{2}=\sqrt{\sigma_{2}^{2}}=\sqrt{0,0001257}=0,0112$

Begitu seterusnya hingga periode waktu terakhir. Dari hasil perhitungan diperoleh hasil nilai volatilitas harian terbaru adalah $\sigma_{j, T}=\sigma_{j, 140}=0,0139$. Nilai ini akan digunakan untuk perrhitungan volatility updating Hull and White.

\subsubsection{Volatility Updating Hull and White}

\subsubsection{Uji Stasioneritas}

$\mathrm{H}_{0}: \beta=1$ (terdapat akar unit atau data tidak stasioner)

$\mathrm{H}_{1}: \beta=0$ (tidak terdapat akar unit atau data stasioner)

Statistik uji dalam pengujian asumsi stasioneritas adalah: $A D F=\frac{\widehat{\beta}-1}{\operatorname{std}(\widehat{\beta})}$

$\mathrm{H}_{0}$ ditolak apabila nilai $p$-value $<\alpha$.

Tabel 5. Uji Stasioneritas Augmented Dickey-Fuller

\begin{tabular}{cccc}
\hline Data & P-Value & $\alpha$ & Keputusan \\
\hline$\frac{R_{p, t}}{s_{p, t}}$ & 0,001 & 0,05 & Hoditolak \\
\hline
\end{tabular}

Berdasarkan Tabel 5, nilai p-value kurang dari nilai $\alpha=5 \%$, sehingga dapat disimpulkan bahwa pada taraf signifikansi $\alpha=5 \%$ data $\frac{R_{p, t}}{s_{p, t}}$ stasioner.

\subsubsection{Perhitungan Return Baru}

Setelah dilakukan uji stasioneritas data $\frac{R_{j, t}}{s_{j, t}}$, diperoleh hasil bahwa data tersebut bersifat stasioner sehingga perlu dilakukan perhitungan return baru. Return dihitung dengan rumus:

$R_{p, t}^{*}=s_{p, T} \frac{R_{p, t}}{s_{p, t}}$

$R_{p, 1}^{*}=s_{p, 139} \frac{R_{p, 1}}{s_{p, 1}}=(0,0138) \frac{0,0066}{0,0114}=0,0079$

Dan seterusnya perhitungan dilakukan hingga periode terakhir. 


\subsubsection{Estimasi VaR}

$$
\text { VaR }=S_{0} \times \text { Percentile } k e-\alpha \times \sqrt{h p}
$$

Untuk periode 5 hari, $\operatorname{VaR}=100000000 \times(-0,01909) \times \sqrt{5}=-4270540$

Untuk periode 20 hari, $V a R=100000000 \times(-0,01909) \times \sqrt{20}=-8541080$

Tabel 10. Hasil Perhitungan VaR dengan Metode Historical Simulation

\begin{tabular}{|c|c|c|c|c|}
\hline Tingkat & Decay & Nilai Persentil & \multicolumn{2}{|c|}{ VaR } \\
\cline { 4 - 5 } Kesalahan $(\alpha)$ & Factor $(\lambda)$ & ke- $\alpha$ & 5 hari & 20 hari \\
\hline $5 \%$ & 0,94 & $-0,01909$ & $-0,0427054$ & $-0,0854108$ \\
\hline
\end{tabular}

Jika investor berinvestasi sebanyak Rp 100.000.000,00 maka diperkirakan ia tidak akan mengalami kerugian lebih dari $-0,0427054 \times \mathrm{Rp} 100.000 .000,00=\mathrm{Rp} 4.270 .540,00$ dengan tingkat kepercayaan $95 \%$ dan jangka waktu investasi 5 hari.Jika investor berinvestasi sebanyak Rp 100.000.000,00 maka diperkirakan ia tidak akan mengalami kerugian lebih dari $-0,0854108 \times \mathrm{Rp} 100.000 .000,00=\mathrm{Rp} 8.541 .080,00$ dengan tingkat kepercayaan $95 \%$ dan jangka waktu investasi 20 hari setelah investasi.

\section{3. $\quad$ Backtesting}

$\mathrm{H}_{0}$ : nilai VaR akurat

$\mathrm{H}_{1}$ : nilai VaR tidak akurat

Statistik uji yang digunakan adalah LR:

$$
L R=-2 \ln \left[(1-p)^{T-m} p^{m}\right]+2 \ln \left[\left(1-\left[\frac{m}{T}\right]\right)^{T-m}\left(\frac{m}{T}\right)^{m}\right]
$$

Dimana LR adalah statistik uji Likelihood Ratio, p adalah probabilitas kegagalan dalam penelitian ini sebesar 0,01, T adalah jumlah obervasi sebanyak 140 dan m adalah jumlah kegagalan yaitu $\mathrm{m}=1$.

$$
L R=-2 \ln \left[(1-0,01)^{140-1}(0,01)^{1}\right]+2 \ln \left[\left(1-\left[\frac{1}{140}\right]\right)^{140-1}\left(\frac{1}{140}\right)^{1}\right]
$$

$$
L R=2,11529
$$

$\mathrm{H}_{0}$ ditolak apabila $\mathrm{LR}<x_{\text {tabel }}^{2}$. Nilai $x_{\text {tabel }}^{2}=x_{0,01 ; 1}^{2}=6,63489 . \mathrm{H}_{0}$ ditolak karena LR $>X_{(0,01 ; 1)}^{2}$ yaitu $2,11529<6,63489$. Jadi dapat disimpulkan bahwa pada taraf signifikansi $5 \%$ estimasi nilai VaR akurat.

\section{KESIMPULAN}

Perhitungan volatilitas dilakukan menggunakan metode EWMA karena ditemukan sifat varian yang tidak konstan atau heteroskedastik. Metode EWMA ini memberikan pembobotan terhadap perubahan harga saham setiap periode dengan menggunakan decay factor $(\lambda)$. Besarnya decay factor $(\lambda)$ yang digunakan ldalam penelitian ini adalah $\lambda=0,94$.

Volatilitas yang diperoleh dari metode EWMA digunakan untuk perhitungan return baru berdasarkan prosedur volatility updating Hull and White. Nilai volatilitas tersebut digunakan untuk menghitung risiko investasi portofolio (VaR). Hasil perhitungan VaR portofolio dari saham ASII, BBNI dan PTBA dengan tingkat kepercayaan 95\% untuk periode waktu investasi selama 5 hari sebesar $-0,0427054$ atau $-4,27054 \%$ dari jumlah total investasi. Sedangkan, untuk periode waktu 20 hari sebesar $-0,0854108$ atau $-8,54108 \%$. Hal ini menunjukkan bahwa semakin lama periode investasi maka presentase kemungkinan kerugiannya akan semakin besar, namun belum bisa dipastikan terjadinya kerugian tersebut. Uji backtesting dilakukan untuk mengetahui valid tidaknya perhitungan VaR yang telah dilakukan. Semua VaR yang diperoleh dari perhitungan valid untuk memprediksi tingkat kerugian investasi berdasarkan uji backtesting PF Kupiec dan aturan Basel. 


\section{DAFTAR PUSTAKA}

Ahmad, K. 2004. Dasar-Dasar Manajemen Investasi dan Portofolio. Jakarta : Rineka Cipta. Buchdadi, A.D. 2008. Perhitungan Value at Risk Portofolio Optimum Saham Perusahaan Berbasis Syariah dengan Pendekatan EWMA. Jurnal Akuntansi dan Keuangan Indonesia Vol.5, No.2 : Hal. 182-201.

Ghozali, I. 2007. Manajemen Risiko Perbankan. Semarang : Badan Penerbit Universitas Diponegoro.

Gujarati, D.N. 2006. Dasar-Dasar Ekonometrika Jilid 2. Diterjemahkan oleh : Julius A. Mulyadi dan Yelvi Andri. Jakarta : Erlangga. Terjemahan dari : Essentials of Econometrics.

Hadi, N. 2003. Acuan Teoritis dan Praktis Investasi di Instrumen Keuangan Pasar Modal. Yogyakarta : Graha Ilmu.

Hull, J. dan White, A. 1998. Incorporating Volatility Updating Into The Historical Simulation Method for Value at Risk. Journal of Risk (Fall), 1, 5-19.

Jorion, P. 2002. Value at Risk: The New Benchmark for Managing Financial Risk Second Edition. New York : The McGraw-Hill Companies, Inc.

Kupiec, P. H. 1995. Techniques for Verifying The Accuracy of Risk Measurement Models. The Journal of Derivatives Vol. 3, No. 2 : Hal. 73-84.

Maruddani, D.A.I, dan Purbowati, A. 2009. Pengukuran Value at Risk pada Aset Tunggal dan Portofolio dengan Simulasi Monte Carlo. Media Statistika Vol. 2, No. 2 : Hal. 93 104.

Morgan, J.P. 1996. RiskMetrics ${ }^{T M}$ Technical Document. Fourth Edition. New York : Morgan Guaranty Trust Company.

Pratiwi,A.E., Dzulkirom, M., dan Azizah, D.F. 2014. Analisis Investasi Portofolio Saham Pasar Modal Syariah Dengan Model Markowitz Dan Model Indeks Tunggal (Studi Pada Saham Perusahaan yang Terdaftar dalam Jakarta Islamic Indeks di Bursa Efek Indonesia Periode Mei 2011 sampai dengan November 2013). Jurnal Administrasi Bisnis Vol. 17, No.1.

Samsul, M. 2006. Pasar Modal dan Manajemen Portofolio. Jakarta : Erlangga.

Tsay, R.S. 2005. Analysis of Financial Time Series Second Edition. New Jersey : John Wiley \& Sons. 